\title{
Mechanism of the Na,K-ATPase Inhibition by MCS Derivatives
}

\author{
R. Stimac ${ }^{1}$, F. Kerek ${ }^{2}$, H.-J. Apell ${ }^{1}$ \\ ${ }^{1}$ Department of Biology, University of Konstanz, 78457 Konstanz, Germany \\ ${ }^{2}$ Max-Planck-Institute for Biochemistry, Am Klopferspitz 18, 82152 Martinsried, Germany
}

Received: 4 April 2005/Revised: 18 August 2005

\begin{abstract}
The previously reported class of potent inorganic inhibitors of $\mathrm{Na}, \mathrm{K}-\mathrm{ATPa} e$, named MCS factors, was shown to inhibit not only $\mathrm{Na}, \mathrm{K}$-ATPase but several P-type ATPases with high potency in the sub-micromolar range. These MCS factors were found to bind to the intracellular side of the $\mathrm{Na}$, $\mathrm{K}$-ATPase. The inhibition is not competitive with ouabain binding, thus excluding its role as cardiac-steroid-like inhibitor of the Na,K-ATPase. The mechanism of inhibition of Na,K-ATPase was investigated with the fluorescent styryl dye RH421, a dye known to report changes of local electric fields in the membrane dielectric. MCS factors interact with the $\mathrm{Na}, \mathrm{K}-\mathrm{ATPa}$ in the $\mathrm{E}_{\mathbf{1}}$ conformation of the ion pump and induce a conformational rearrangement that causes a change of the equilibrium dissociation constant for one of the first two intracellular cation binding sites. The MCS-inhibited state was found to have bound one cation $\left(\mathrm{H}^{+}, \mathrm{Na}^{+}\right.$or $\left.\mathrm{K}^{+}\right)$in one of the two unspecific binding sites, and at high $\mathrm{Na}^{+}$ concentrations another $\mathrm{Na}^{+}$ion was bound to the highly $\mathrm{Na}^{+}$-selective ion-binding site.
\end{abstract}

Key words: P-type ATPase - Active ion transport — Ion binding - Enzyme activity — Fluorescence Styryl dye

\section{Introduction}

The Na,K-ATPase is in almost all animal cells the major determinant of the cytoplasmic $\mathrm{Na}^{+}$concentration. This active ion transporter regulates cell volume, cytoplasmic $\mathrm{pH}$ and $\mathrm{Ca}^{2+}$ concentrations through, e.g., the $\mathrm{Na}^{+} / \mathrm{H}^{+}-$and $\mathrm{Na}^{+} / \mathrm{Ca}^{2+}$ exchangers, and drives a variety of secondary trans-

Correspondence to: H.-J. Apell; email: h-j.apell@uni-konstanz.de port processes (Lang et al., 1998). Regulation of the pump is primarily necessary because of variations in dietary uptake of $\mathrm{Na}^{+}$and $\mathrm{K}^{+}$, and will mostly be necessary in tissues with high changes of internal and external cation concentrations (e.g., signaling in neuronal tissue, effects of exercise on muscle tissue, renal reabsorption of salts). Hormones that regulate the ionic composition of blood and urine often act directly on the Na,K-ATPase (Therien \& Blostein, 2000). Since water and $\mathrm{Na}^{+}$transport across epithelia are invariably linked, the Na,K-ATPase is also crucial to water absorption in the intestine and reabsorption in the kidneys. This connection was repeatedly proven by reports showing that altered $\mathrm{Na}, \mathrm{K}$-ATPase activity is associated with the pathophysiology of hypertension (Hussain \& Lokhandwala, 2003), chronic diarrhea (Fondacaro, 1986) and other diseases. Variations in the expression of isoforms may fulfill some regulatory requirements, but in the meanwhile an abundance of regulatory mechanisms has been reported for the Na,K-ATPase, such as changes in substrate concentrations induced by membrane-associated components, circulating endogenous inhibitors, and hormonal regulation (Therien \& Blostein, 2000).

In addition, the Na,K-ATPase may be affected by exogenous inhibitors. Classical inhibitors from plants, like digitalis and ouabain, so-called cardiac steroids, are well known for centuries for their therapeutic application (Erdmann, Greef \& Skou, 1986). Besides the utilization to strengthen the activity of the cardiac muscles, these inhibitors are applied in basic research to analyze the mechanism by which the $\mathrm{Na}, \mathrm{K}$-ATPase translocates cations across biological membranes, utilizing the free energy of ATP hydrolysis. Any inhibitor that blocks the ion pump in a defined state has the potential to promote the understanding of the transport mechanism. By this means unknown intermediate steps in the reaction cycle as well as more detailed structure-function 
relationships might be uncovered. Therefore, it is of wider interest to find and characterize new inhibitors of the Na,K-ATPase, inhibitors that are able to block the ion pump in states other than cardiac glycosides do, in order to discover further details of the mechanism of ion pumping.

We previously reported that the so-called MCS factors are of inorganic nature and strong inhibitors of the Na,K-ATPase and other P-type ATPases (Kerek et al., 2002). It was furthermore remarked that these novel Na,K-ATPase inhibitors share many properties with putative endogenous digitalis-like factors (EDLF) (Kerek, 2000). Worth mentioning are identical mass ion values in mass spectra of MCS factors and the previously reported EDLFs, $\mathrm{pH}$ and concentration-dependent variations of their inhibitory activity, or sudden loss of activity that cannot be prevented by freezing (Kerek et al., 2002). Our recent findings confirmed all the previously reported spectral and ATPase enzyme inhibitory properties of MCS. Although the inorganic nature of MCS factors is not contested, its previously assumed structure was revised and will be published separately in detail. The revised structure of MCS factors was definitely confirmed by their synthetic preparation, through which the same highly potent Na,K-ATPase inhibitors were obtained. Therefore, in the present study, the mechanism of inhibition of Na,K-ATPase by MCS factors was examined in order to gain insights into how and in which state(s) they inhibit the ion pump, and to elucidate whether and how they might be involved in the regulation of $\mathrm{Na}, \mathrm{K}$-ATPase or other P-type ATPases.

\section{Materials and Methods}

\section{Chemicals}

Phosphoenolpyravate (PEP), pyravate kinase (PK), lactate dehydrogenase (LDH), NADH and ATP (disodium salt, special quality) were from Boehringer (Mannheim). The electrochromic styryl dye RH421 was ordered from MoBiTec, Göttingen, Germany. All other reagents were purchased from Merck (Darmstadt) or SigmaAldrich (Deisenhofen) at the highest quality available.

\section{Preparation of Active MCS Factors}

$1 \mathrm{mg}$ of the purified and lyophilized MCS precursor (Kerek, 2000) was dissolved in a mixture of $1 \mathrm{ml} 50 \%$ ethanol, and $5 \mathrm{ml} 1.2 \mathrm{M}$ $\mathrm{NaOH}$ to a final concentration of $0.167 \mathrm{mg} / \mathrm{ml}$ of the precursor. The alkaline solution was boiled in a $10 \mathrm{ml}$ round-bottom glass flask equipped with a water-cooled condenser under slow stirring in an oil bath $\left(116^{\circ} \mathrm{C}\right)$. The optimal boiling time to obtain the active MCS factor was found to be 8 to $14 \mathrm{~h}$ (see below). After boiling, the alkaline solution was adjusted with $1 \mathrm{M} \mathrm{HCl}$ to a $\mathrm{pH}$ value of 7.0 to 7.5. To remove the $\mathrm{Na}^{+}$ions, the neutralized solution was treated with a strong cation-exchanger resin, e.g., $40 \mathrm{mg}$ of Am-

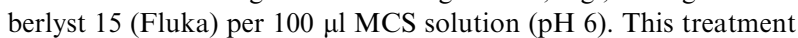
further decreased the $\mathrm{pH}$ to values of 3 or less. Several details in the preparation of the highly active MCS factors are apparently of decisive importance, although the underlying chemical processes are not yet understood (Stimac, 2005). Thus, a too rapid acidification of the boiled alkaline probe from $\mathrm{pH}>13$ to acidic $\mathrm{pH}$ values can lead to a gel-like and inactive substance. Titration with diluted $\mathrm{HCl}$ (less than $1 \mathrm{M}$ ) produces very potent inhibitors, but their activity decays within a few days of storage.

\section{CATION Exchanger}

After neutralization, the MCS factor samples were treated with cation exchanger in order to remove excess $\mathrm{Na}^{+}$ions. The dry cation exchanger resin Amberlyst 15 (Fluka) needed to be carefully washed before being applied to the solutions of MCS factors because it may contain very small powdered particles, which interfere with the fluorescence of the styryl dye. In order to prevent this, the amount of dry Amberlyst 15 resin needed was filled into an Eppendorf cup and then washed with at least $6 \times 1 \mathrm{ml}$ quartz-distilled $\mathrm{H}_{2} \mathrm{O}\left(\mathrm{dH}_{2} \mathrm{O}\right)$ by applying each time $1 \mathrm{ml}$ to the Eppendorf cup, thoroughly mixing the cation exchanger in solution for about 1 min and removing the excess $\mathrm{dH}_{2} \mathrm{O}$ containing the contaminants before applying another $1 \mathrm{ml}$ of $\mathrm{dH}_{2} \mathrm{O}$. In a control experiment, a 1 M solution of $\mathrm{NaOH}$ was prepared, then neutralized with the same amount of $1 \mathrm{M} \mathrm{HCl}$ as used in neutralizations of MCS factors, and then mixed thoroughly with washed cation-exchanger resin. This control solution did not alter the fluorescence properties when added to the solution in the cuvette of the experimental setup.

\section{ENZYMe Assays}

Membrane preparations with a high concentration of $\mathrm{Na}$, K-ATPase (about 5.000 pumps per $\mu^{2}$ ) were prepared from the outer medulla of rabbit and rat kidneys using the procedure $\mathrm{C}$ of Jørgensen (Jørgensen, 1974). The specific ATPase activity was in the range of 2.000 to $2.400 \mu \mathrm{mol} \mathrm{P}_{\mathrm{i}}$ per hour and $\mathrm{mg}$ protein at $37^{\circ} \mathrm{C}$ for the rabbit enzyme and $2000 \mu \mathrm{mol} \mathrm{P}_{\mathrm{i}}$ per hour and $\mathrm{mg}$ protein for the rat enzyme. The enzyme activity of the $\mathrm{Na}, \mathrm{K}$ ATPase (Schwartz et al., 1971) was determined in buffer containing $25 \mathrm{~mm}$ imidazole ( $\mathrm{pH} 7.2$ ), $100 \mathrm{~mm} \mathrm{NaCl}, 10 \mathrm{~mm} \mathrm{KCl}, 5 \mathrm{~mm}$ $\mathrm{MgCl}_{2}, 1.5 \mathrm{~mm} \mathrm{Na}{ }_{2} \mathrm{ATP}, 2 \mathrm{~mm}$ phosphoenol-pyruvate (PEP), 450 units/ml of pyruvate kinase (PK) and lactate dehydrogenase (LDH), and initially $80 \mu \mathrm{M}$ NADH. All experiments were performed at $37^{\circ} \mathrm{C}$. The enzyme activity in absence of inhibitor was used as reference. Molar concentrations of the MCS solution were calculated with a presumed molar mass of $408.2 \mathrm{Da}$ as estimated from mass spectra. The actual molar mass, $\mathrm{Mr}$, of the active MCS factors is based on small multiples of this 408.2 Da mass ion value but a direct assessment of the exact $\mathrm{Mr}$ of the MCS was experimentally not possible in the framework of the inhibitory assay. The PK/LDH assay was not affected by MCS, as was proven by a control experiment with $\mathrm{Na}_{2}$-ADP (see below). In the presence of $125 \mu \mathrm{M}$ ouabain, the Na,K-ATPase preparation was fully inhibited, a fact which confirmed the high degree of purity of the enzyme preparation as additionally controlled by sodium dodecyl sulfate polyacrylamide gel electrophoresis (SDS-PAGE). The normalized specific activity was calculated as the ratio of the residual activity upon addition of given amounts of inhibitor, and the reference activity before.

Ca-ATPase was prepared from rabbit psoas muscle by a slight modification of the method of Heilmann (Heilmann et al., 1977). The whole isolation procedure was performed at temperatures below $4^{\circ} \mathrm{C}$. The protein content of the membrane preparation was found to be $2-3 \mathrm{mg} / \mathrm{ml}$ for the most active fractions after the final density gradient separation. The specific enzymatic activity was about $2 \mu \mathrm{mol} \mathrm{Pi}$ per hour and $\mathrm{mg}$ protein at $20^{\circ} \mathrm{C}$. The enzyme activity was determined by the same coupled $\mathrm{PK} / \mathrm{LDH}$ assay as in 
the case of the $\mathrm{Na}, \mathrm{K}-\mathrm{ATPa} e$, using buffer ( $\mathrm{pH}$ 7.5) containing $25 \mathrm{~mm}$ HEPES, $1 \mathrm{~mm} \mathrm{MgCl}_{2}, 50 \mathrm{~mm} \mathrm{KOH}$, and $0.2 \mathrm{~mm} \mathrm{CaCl}_{2}$. Background enzyme activity of the isolated preparation was obtained by addition of $1 \mu \mathrm{M}$ thapsigargin. The specific activity of the Ca-ATPase preparation was $\sim 1.8$ units $/ \mathrm{mg}$ at $20^{\circ} \mathrm{C}$ and $\mathrm{pH} 7.5$ (which corresponds to $1.8 \mu \mathrm{mol}$ ATP hydrolyzed per mg protein per min).

Gastric H,K-ATPase was made available by Dr. Olga Vagin, UCLA. It was derived from hog gastric mucosa by previously published methods, which involve differential and density gradient centrifugation (Rabon, Bin \& Sachs, 1988). The crude gastric mucosal membrane is collected from the stomach and homogenized in a solution of $0.25 \mathrm{~m}$ sucrose, $5 \mathrm{~mm}$ PIPES/Tris, $\mathrm{pH} 6.8$, and $1 \mathrm{~mm}$ EGTA. The homogenate is centrifuged at $19,700 \times g$ in a Sorvall GSA rotor for $45 \mathrm{~min}$. The supernatant is centrifuged at $100,000 \times g$ in a Beckman type 30 rotor for $1 \mathrm{~h}$. The microsomal pellet is resuspended in a solution of $0.25 \mathrm{~m}$ sucrose, $5 \mathrm{~mm}$ PIPES/Tris, $\mathrm{pH}$ 6.8 , and $1 \mathrm{~mm}$ EGTA. Then, the microsomal suspension is purified using a Z-60 zonal rotor.

\section{Enzyme Vesicle Preparation}

$\mathrm{Na}, \mathrm{K}-\mathrm{ATPa} e$ vesicles were prepared using the following procedure (for more details, see Apell et al., 1985, Alpes et al., 1988): Purified rabbit $\mathrm{Na}, \mathrm{K}$-ATPase $(\sim 150 \mu \mathrm{g})$ was solubilized in $74 \mu \mathrm{l}$ sodium cholate (1\%). Lipid / detergent mixtures were prepared from stock solutions of dioleoyl phosphatidylcholine (DOPC) in chloroform. The solvent was evaporated under vacuum in a round-bottom flask to yield a thin film on the glass wall. Then the lipid was solubilized by addition of sodium cholate to yield a concentration of $20 \mathrm{mg} / \mathrm{ml}$. $56 \mu \mathrm{l}$ of this DOPC solution was added to the Na,K-ATPase solution and dialyzed overnight against $500 \mathrm{ml}$ buffer $(30 \mathrm{~mm}$ imidazole, $1 \mathrm{~mm}$ EDTA, $5 \mathrm{~mm} \mathrm{MgCl}_{2}$, $\mathrm{pH}$ 7.2). Protein concentration was determined with a Markwell test and typically resulted in $\sim 0.4 \mathrm{mg} / \mathrm{ml}$.

\section{Fluorescence Experiments with Styryl Dye RH421}

RH421 is an amphiphilic styryl dye that dissolves in lipid membranes with a partition coefficient of $2.5 \times 10^{5}$ (Bühler et al., 1991) with its negatively charged sulfonyl residue directed towards the aqueous phase. By absorption of a photon of proper wavelength, the dye can be excited with its positive charge shifted from the pyridine unit of the chromophore towards the more interior placed aniline unit (Pedersen et al., 2001). The spectral changes of the styryl dye are predominantly results from an electrochromic effect, i.e., a shift of the absorption band occurs when the energy difference between ground state and excited state depends on electric field strength. The electric field may also affect the fluorescence quantum yield.

The local electric field strength changes by charge translocations in the course of the pump cycle of the Na,K-ATPase, and the styryl dye responds with shifts of the emission spectra to longer (red) or shorter (blue) wavelength, corresponding to changes of the (local) electric potential inside the membrane to more negative or more positive values, respectively (Bühler et al., 1991).

In conclusion, the reaction sequence leading to the observed fluorescence changes in the experiments can be described as follows: the styryl dye RH421 is always excited at the red edge of the absorption band at $594 \mathrm{~nm}$ and the emitted fluorescence is detected at $660 \mathrm{~nm}$. Movement of the positive charge within the styryl dye towards the interior of the membrane in the presence of an insidenegative potential leads to a decrease of the energy difference between excited and ground states, hence a red shift of the absorption spectrum occurs, resulting in an increase of fluorescence. An insidepositive membrane potential leads to an increase of the energy

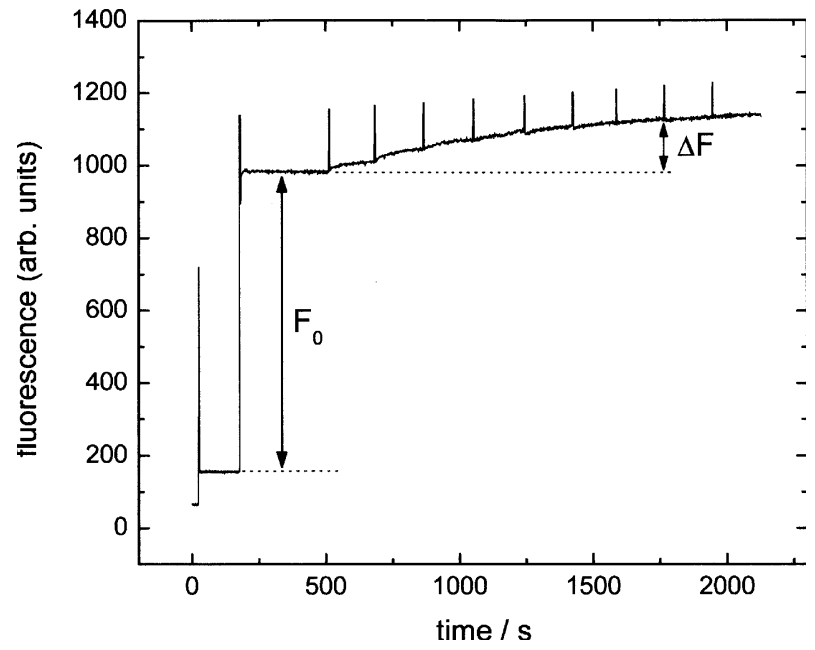

Fig. 1. Typical fluorescence experiment showing a titration of MCS factors to rabbit $\mathrm{Na}, \mathrm{K}-\mathrm{ATP}$ ase in state $\mathrm{E}_{1}$. Labels indicate fluorescence levels $F_{0}$ and $\Delta F$, which were used subsequently to calculate relative fluorescence levels. $2 \mathrm{ml}$ buffer ( $30 \mathrm{~mm}$ imidazole, $1 \mathrm{~mm}$ EDTA, pH 7.0). Additions: $1 \mu \mathrm{RH} 4210.2 \mathrm{~mm}, 3 \mu \mathrm{lrabbit}$ Na,K-ATPase $1.5 \mathrm{mg} / \mathrm{ml}, 1 \mu \mathrm{l}$ MCS $(0.08 \mathrm{mg} / \mathrm{ml}), 3 \times 2 \mu \mathrm{l} \mathrm{MCS}$ $(0.08 \mathrm{mg} / \mathrm{ml}), 5 \times 4 \mu \mathrm{MCS}(0.08 \mathrm{mg} / \mathrm{ml})$.

difference between excited and ground states, hence a blue shift of the absorption spectrum occurs, resulting in a decrease of fluorescence.

The raw data obtained from a fluorescence experiment in arbitrary units (Fig. 1) was transformed to display $\Delta F / F_{0}=(F$ $\left.F_{0}\right) / F_{0}$ on the vertical axis, thereby normalizing the fluorescence values to the initial fluorescence level, $F_{0}$, so that different experiments can be compared easily. Furthermore, in typical titration experiments the fluorescence levels after each addition of MCS factors were calculated by averaging the fluorescence intensities during a longer time period (at least 30 seconds). These values were also corrected for dilution effects.

\section{Mathematical Simulation of Experimental RESUlts}

In order to determine the reaction mechanism of MCS factors we tried to simulate the data obtained from equilibrium-titration experiments with models of a reaction scheme that was proposed to fit the actual data. These algebraic calculations were performed with Mathematica 4, which provided the analytical solution of the linear-equation systems of a proposed reaction scheme, and Mathcad V.11.0b, which allowed the visualization of the simulated reactions and their comparison with experimental data. Hypothetical reaction schemes were at first limited to the respective partial reactions that were measured in the fluorescence experiments. Thus, the simulations at the beginning were carried out containing only the states presented in boxes I to III drawn in Fig. 9. Implicit in this reaction scheme is the assumption that all non-inhibited states of the Na-K-ATPase are not affected by the MCS factors.

By starting the data analysis with the experiments in absence of $\mathrm{Na}^{+}$and $\mathrm{K}^{+}$according to box I and using the values of $\mathrm{pK} 1$ and pK2 from the literature (Apell \& Diller, 2002) only one free parameter, KHI1, had to be determined. In the next step, the experiments in the presence of $\mathrm{K}^{+}$were fitted by the reaction scheme of Box II. The parameters obtained in the first step and the equilibrium dissociation constants for $\mathrm{K}^{+}$from the literature 
Table 1. Equilibrium dissociation constants and fluorescence levels assigned to the final reaction scheme (Fig. 9) that best fit the experimental data

\begin{tabular}{lcll}
\hline Enzyme state & Fluorescence & Kinetic parameter & mol per 1 \\
\hline $\mathrm{E}_{1}$ & 0.45 & $\mathrm{pK} 1$ & 6.76 \\
$\mathrm{HE}_{1}$ & 0.20 & $\mathrm{pK} 2$ & 9.9 \\
$\mathrm{H}_{2} \mathrm{E}_{1}$ & 0.00 & $\mathrm{KHI} 1$ & $3.39 \cdot 10^{-4}$ \\
$\mathrm{HE}_{1} \mathrm{I}$ & 0.25 & $\mathrm{KNa} 1$ & $1.00 \cdot 10^{-6}$ \\
$\mathrm{KE}_{1}$ & 0.25 & $\mathrm{KNa} 2$ & $9.28 \cdot 10^{-3}$ \\
$\mathrm{~K}_{2} \mathrm{E}_{2}$ & -0.03 & $\mathrm{KNa} 3$ & $9.00 \cdot 10^{-6}$ \\
$\mathrm{KHE}_{1}$ & 0.02 & $\mathrm{pK} 4$ & 9.17 \\
$\mathrm{KE}_{1} \mathrm{I}$ & 0.22 & $\mathrm{KNaI} 1$ & $2.76 \cdot 10^{-3}$ \\
$\mathrm{NaE}_{1}$ & 0.12 & $\mathrm{KNaI} 3$ & $1.15 \cdot 10^{2}$ \\
$\mathrm{Na}_{2} \mathrm{E}_{1}$ & 0.03 & $\mathrm{KK} 1$ & $4.50 \cdot 10^{-5}$ \\
$\mathrm{Na}_{3} \mathrm{E}_{1}$ & -0.18 & $\mathrm{KK} 2$ & $1.06 \cdot 10^{-4}$ \\
$\mathrm{NaHE}_{1}$ & -0.05 & $\mathrm{pK} 3$ & 8.57 \\
$\mathrm{NaE}_{1} \mathrm{I}$ & 0.31 & $\mathrm{KKI} 1$ & $3.55 \cdot 10^{-3}$ \\
$(\mathrm{Na}) \mathrm{NaE}$ & & & \\
\hline
\end{tabular}

(Schulz \& Apell, 1995) were kept constant so that only two free constants, pK3 and KKI1, had to be determined. In a third step the $\mathrm{Na}^{+}$dependence was analyzed according to the scheme in Box III. Again, the parameters from Box I and the equilibrium dissociation constants for $\mathrm{Na}^{+}$from the literature (Schneeberger \& Apell, 1999) were kept constant, and three free parameters, $\mathrm{pK} 4, \mathrm{KNaI} 1$, and $\mathrm{KnaI3}$, were determined. Only after the simulations of the three partial schemes were in close proximity to the experimental data, the models were merged to result in the final reaction scheme presented in Fig. 9 and all parameters, fluorescence levels, binding constants, and MCS factor activation constants, were allowed to vary in order to obtain a least square fit. No significant variations were observed with respect to the initially obtained values, and the results are presented in Table 1.

Since relative fluorescence levels were obtained from the experiments, it was necessary to assign corresponding fluorescence levels to each state introduced in the hypothetical model with respect to the (identical) initial reference state. E.g., a state $\mathrm{E}_{1} \mathrm{H}$ with one cation bound to the enzyme would be assigned a fluorescence level of $\sim 0.2$, a state $\mathrm{E}_{1} \mathrm{~K}_{2}$ would be assigned a fluorescence level of $\sim 0.0$ and a state- $\mathrm{E}_{1} \mathrm{Na}_{3}$ would be assigned a fluorescence level of $\sim-0.2$, corresponding to the fact that the maximal fluorescence change occurs in the transition from $\mathrm{Na}_{3} \mathrm{E}_{1}$ to $\mathrm{E}_{2} \mathrm{P}$ and this fluorescence change is measured at $\sim 0.6$ (resulting in one third of 0.6 for each ion released). Based on the known mechanism of styryl dyes, the reasonable assumption was made that MCS factors do not affect RH421 and its mechanism.

Finally, to calculate the theoretical fluorescence level under given experimental conditions the fractions of enzymes in their respective states were multiplied with the corresponding fluorescence levels resulting in shares of fluorescence for each state and then summed up resulting in the total fluorescence level under given theoretical conditions.

\section{Results}

\section{EnZyme Specificity of MCS Factors}

It was already reported that MCS factors are of inorganic nature and inhibit strongly not only the $\mathrm{Na}, \mathrm{K}-\mathrm{ATPase}$ but also the SR Ca-ATPase (Kerek, 2000, Kerek et al., 2002). In a systematic study, available ATPase preparations were tested in order to determine the range of inhibition. The inhibitory activity of the MCS factors (here, batch PBNA-L02) was determined by an enzyme assay as described in the Methods section. The inhibitor concentration was step-wise increased up to $10 \mu \mathrm{m}$ and the amount of inhibited ion pumps (normalized to the total enzyme activity) plotted against the inhibitor concentration (Fig. 2). In Fig. $2 A$ representative results obtained with $\mathrm{Na}, \mathrm{K}$-ATPase are shown. It can be seen that the MCS inhibitors are about a factor of ten more potent than ouabain in the case of rabbit-kidney $\mathrm{Na}, \mathrm{K}$ ATpase. Na,K-ATPase from rat kidney, which is known to be significantly less sensitive to ouabain than the rabbit enzyme (not shown), shows a rather similar dose-response curve for both enzyme preparations (Fig. 2A). When applied to the SR Ca-ATPase of rabbit muscle and to the H,K-ATPase from hog stomach, the MCS factors were able to inhibit the enzyme activity with half-inhibitory concentrations, $K_{1 / 2}$, in the range of $0.1 \mu \mathrm{M}$. (Fig. $2 B$ ). In addition, experiments were performed with a crude microsomal preparation from rabbit kidney, which forms leaky inside-out vesicles. It is known that this preparation contains as a major fraction the $\mathrm{Na}, \mathrm{K}$ ATPase but also a $\mathrm{Mg}^{2+}$-ATPase and $\mathrm{F}$ - and/or V-type ATPases that account for about $30 \%$ of the total ATPase activity and that can be inhibited by $\mathrm{Na}_{3} \mathrm{~N}$. In enzyme-assay experiments the non P-type ATPases were inhibited by $15 \mu \mathrm{M} \mathrm{Na}_{3} \mathrm{~N}$ in a first step, and subsequently the remaining ATPase activity could be blocked completely by MCS factors. In the case of inhibition by saturating concentrations of ouabain, a residual ATPase activity of $15 \%$ remained, which was attributed to a $\mathrm{Mg}^{2+}$-ATPase (Jørgensen $\&$ Skou, 1971) in the microsomal preparation (Fig. $2 C$ ). These findings indicate that the MCS factors are possibly general inhibitors of P-type ATPases.

\section{SidedNESS OF INHIBITOR BINDING}

In order to determine the site of inhibitor interaction with the $\mathrm{Na}, \mathrm{E}-\mathrm{ATPa} e$, experiments with $\mathrm{Na}, \mathrm{K}$ ATPase reconstituted in DOPC lipid vesicles were carried out, since in these experiments interaction with the intracellular and extracellular side of the protein can be distinguished. Furthermore, competition experiments with MCS factors and ouabain were carried out to reveal a potential interaction with the ouabain binding site.

$\mathrm{Na}, \mathrm{K}$-ATPase is incorporated into the lipid vesicles in both ways, inside-out and right-side out with equal shares (Anner et al., 1984). Addition of ATP activates only inside-out oriented ion pumps, and the enzyme activity can be detected by the $\mathrm{LDH} / \mathrm{PK}$ assay (see Methods). Experimental work has proven that the right-side out population does not contribute 

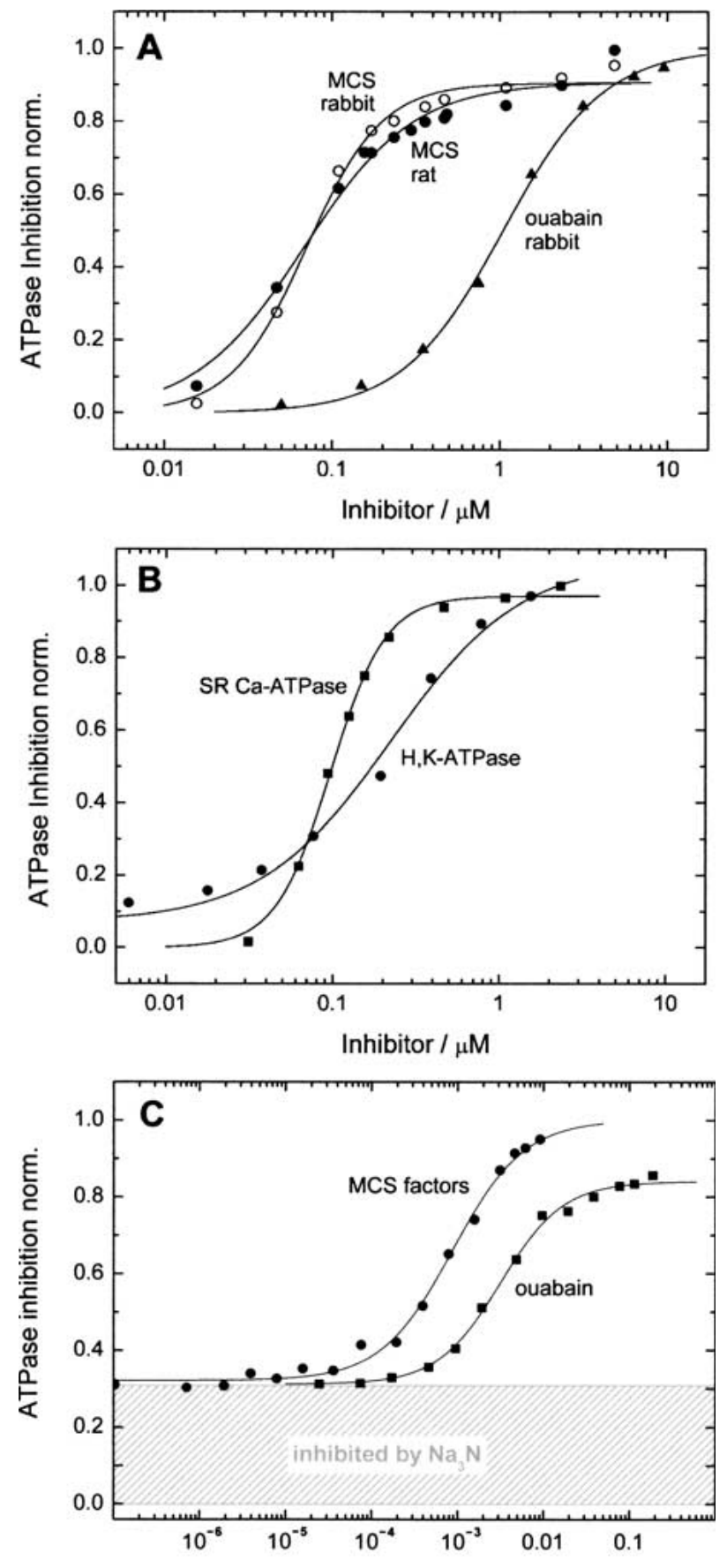

Inhibitor / mM

Fig. 2. Comparison of inhibition by ouabain and MCS factor of different type II P-type ATPases. (A) Inhibition of rabbit Na,KATPase by ouabain $\left(K_{1 / 2}=1.043 \pm 0.031 \mu \mathrm{M}\right)$, and MCS factors $\left(K_{1 / 2}=70 \pm 4 \mathrm{nM}\right)$, and inhibition of rat Na,K-ATPase by MCS factors $\left(K_{1 / 2}=68 \pm 6.4 \mathrm{nM}\right)$. $(B)$ MCS-factor inhibition of SR Ca-ATPase $\left(K_{1 / 2}=97 \pm 2.2 \mathrm{nM}\right)$, and of gastric $\mathrm{H}, \mathrm{K}$ ATPase $\left(K_{1 / 2}=224 \pm 3.1 \mathrm{nM}\right)$. (C) Inhibition of a crude microsomal preparation containing several types of ATPases by MCS factors $\left(\mathbf{O}, K_{1 / 2}=1.04 \pm 0.18 \mu \mathrm{M}\right)$ and ouabain $\left(\mathbf{\square}, \mathrm{K}_{1 / 2}\right.$ $=3.12 \pm 0.24 \mu \mathrm{M})$. About $30 \%$ of the total enzyme activity was inhibited by sodium azide. Buffer composition and calculation of inhibition as described in Materials and Methods for enzyme assays.

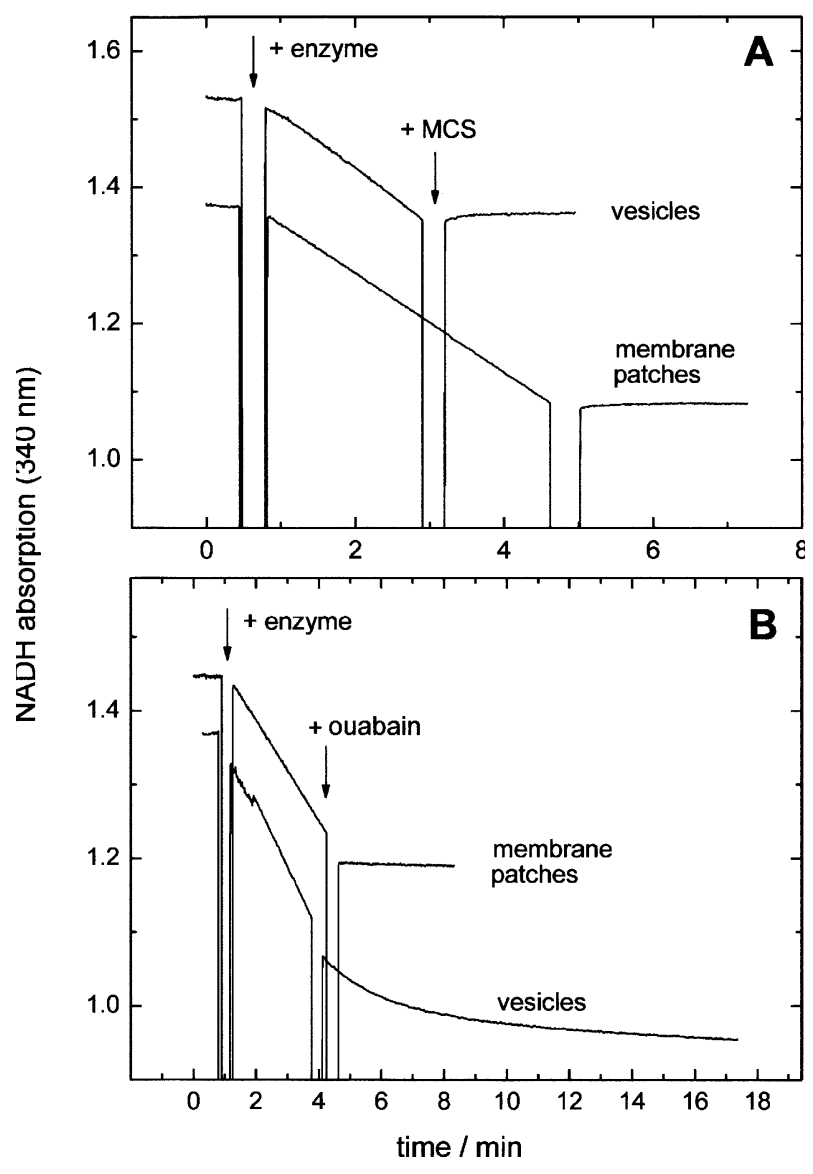

Fig. 3. Inhibition of $\mathrm{Na}, \mathrm{K}-\mathrm{ATP}$ ase in purified membrane preparations of rabbit enzyme and in lipid vesicles containing the same rabbit enzyme, induced $(A)$ by $7.35 \mu \mathrm{M}$ MCS factors and $(B)$ by $100 \mu \mathrm{M}$ ouabain at $37^{\circ} \mathrm{C}$. Buffer composition: $25 \mathrm{mM}$ imidazole (pH 7.2), $100 \mathrm{mM} \mathrm{NaCl}, 10 \mathrm{mM} \mathrm{KCl}, 5 \mathrm{mM} \mathrm{MgCl}_{2}, 1.5 \mathrm{mM}$ $\mathrm{Na}_{2} \mathrm{ATP}, 2 \mathrm{mM}$ PEP, 450 units/ml of pyruvate kinase and lactate dehydrogenase, and initially $80 \mu \mathrm{M} \mathrm{NADH}$. Arrows indicate addition of $0.45 \mu \mathrm{g}$ rabbit $\mathrm{Na}, \mathrm{K}-\mathrm{ATPase}(+$ enzyme) in form of membrane preparation or vesicles and inhibitors $(+$ MCS factors or + ouabain).

to the detected enzyme activity, since permeation of ATP and ADP through the vesicle membrane is negligibly low (Apell et al., 1985). Comparison of experiments with ouabain and MCS-factor inhibition of enzyme-containing vesicle preparations show clearly an almost instant inhibition of ATPase activity by MCS factors (Fig. 3A). Much slower inhibition kinetics are seen when ouabain, which is known to bind to the extracellular side of the Na,KATPase, is added to the assay (Fig. $3 B$ ). Both inhibitors block the enzyme activity immediately when both sides of the membrane are accessible, as it is the case in corresponding experiments with nonvesicular membrane fragments (Fig. 3). The delayed inhibition of ouabain is assigned to the slow diffusion of the (hydrophilic) inhibitor through membrane leaks. Once inside the vesicles, it is able to bind to the "extracellular" side of the inside-out oriented ion 
pumps whose enzyme activity is detected by the assay. The instant effect of MCS factors in the vesicle preparation indicates that the binding site has to be on the cytoplasmic side of the Na, K-ATPase.

In order to gain information about the binding site, the competition between MCS factors and ouabain was investigated with purified membrane preparations of the Na,K-ATPase. In ATPase assays with both inhibitors, MCS factors and ouabain, the inhibition kinetics of one inhibitor was measured in the presence of various concentrations of the other. Although both inhibitors could theoretically compete for the same binding site, no changes in half saturating concentrations, $K_{1 / 2}$, could be observed (neither for ouabain binding nor for MCS factor binding). This non-competitive inhibition suggests that MCS-factors do not bind to the Na,K-ATPase at the extracellular ouabain-binding site.

\section{pH Dependence of the InHibitory Activity}

Since the important role of $\mathrm{pH}$ for the activation procedure of MCS factors was clearly established, the $\mathrm{pH}$ dependence of the inhibitory activity was studied under conditions when buffer $\mathrm{pH}$ did not significantly affect the Na-K-ATPase enzyme activity, i.e., with saturating $\mathrm{Na}^{+}, \mathrm{K}^{+}$, and ATP concentrations (Apell $\&$ Marcus, 1986). ATPase assays were performed as described above, however, with buffer adjusted to a $\mathrm{pH}$ between 6.8 and 7.8 to reveal a possible $\mathrm{pH}$ dependence. The $\mathrm{pH}$ dependence of the dose-response curves of MCS factors on Na,K-ATPase activity is shown in Fig. 4. The half-inhibitory concentration, $K_{1 / 2}=75 \pm 3 \mathrm{nM}$, was not significantly affected by the buffer $\mathrm{pH}$. The MCS titration curves could be fitted with a Hill equation. With increasing $\mathrm{pH}$, the maximal inhibition decreased to about $90 \%$, and the Hill coefficient of fitted experimental data decreased from 1.6 to 1.16 .

\section{MCS Dependence of Partial Reactions of the $\mathrm{Na}, \mathrm{K}-\mathrm{ATP}$ ASE}

Experiments with the fluorescent styryl dye RH421 are well established to monitor certain states of the $\mathrm{Na}, \mathrm{K}$-ATPase, namely $\mathrm{E}_{1}, \mathrm{E}_{1} \mathrm{Na}_{3}, \mathrm{P}-\mathrm{E}_{2}, \mathrm{E}_{2}\left(\mathrm{~K}_{2}\right)$, and to investigate the transitions between them (Heyse et al., 1994), as indicated in the pump cycle of the Na,K-ATPase. These states of the enzyme represent steady-states and can easily be induced and stabilized by sequential application of the ligands, $25 \mathrm{~mm} \mathrm{NaCl}, 0.5 \mathrm{~mm} \mathrm{Na}$-ATP, and $10 \mathrm{~mm}$ $\mathrm{KCl}$. The addition of inhibitor $(1.96 \mu \mathrm{M}$ MCS factors) to the different states and the effects on fluorescence gave a first insight of where an interaction takes place (Fig. 5A-D). An inspection of the fluorescence traces shows that upon addition of the inhibitor in states $\mathrm{P}-\mathrm{E}_{2}$, and $\mathrm{E}_{2}\left(\mathrm{~K}_{2}\right)$, when

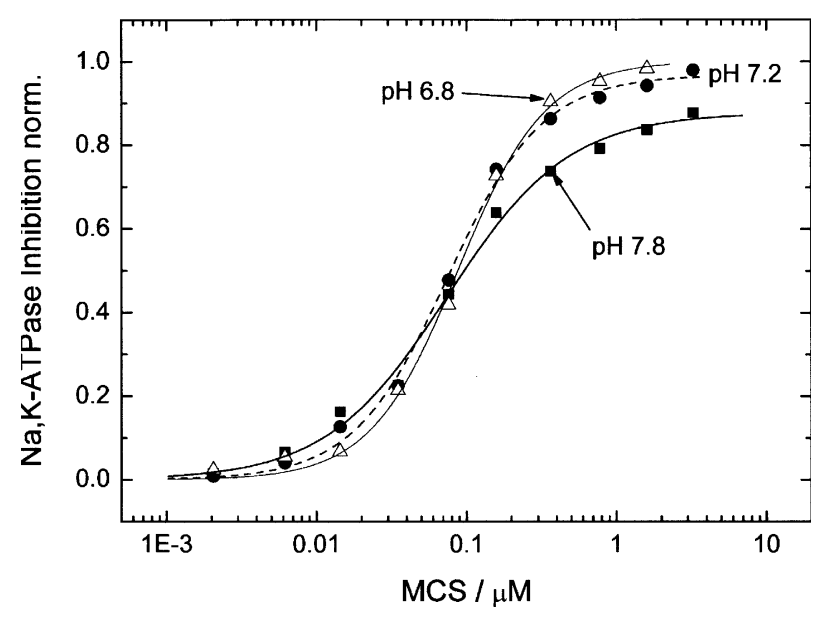

Fig. 4. Rabbit $\mathrm{Na}, \mathrm{K}-\mathrm{ATPa} e$ is inhibited with MCS factors at varying buffer $\mathrm{pH}\left(21^{\circ} \mathrm{C}\right)$. Lines represent fits to the corresponding data points with a Hill equation. The Hill coefficient as calculated for the corresponding curves were for $(\square): n_{\mathrm{H}}=1.16 \pm 0.135$. For (๑): $n_{\mathrm{H}}=1.43 \pm 0.111$. For $(\Delta): n_{\mathrm{H}}=1.6 \pm 0.109$. Buffer composition and calculation of inhibition as described in Materials and Methods.

the substrates are present to allow work under turnover condition, the fluorescence amplitudes - and thus the steady states of the enzyme-were not significantly affected (Fig. 5A,B). When MCS factors were added to the two states in the $E_{1}$ conformation, assigned $E_{1}$ and $\mathrm{Na}_{3} E_{1}$ (Fig. 5C,D), decreased fluorescence changes were found upon ligand additions after addition of the MCS factors. This observation indicates that the inhibitor has modified the apparent binding affinity of the ion binding sites. In consequence, the steady states following in the pump reaction cycle upon addition of ATP and $\mathrm{K}^{+}$were not as highly populated in presence of MCS factors as they were in the absence of MCS factors.

Upon addition of high enough concentrations of MCS factors $\left(>5 \mu \mathrm{M}\right.$ ) to state $\mathrm{Na}_{3} \mathrm{E}_{1}$, no fluorescence increase was observed when ATP was added (not shown), indicating that the enzyme was completely trapped in the $E_{1}$ conformation and phosphorylation was blocked, since at no time a considerable fraction of the pumps populated state $\mathrm{E}_{1} \mathrm{Na}_{3}$ from where they could be phosphorylated in absence of inhibitor. In conformation $\mathrm{P}_{-} \mathrm{E}_{2}$ the addition of any MCS-factor concentration did not affect significantly the fluorescence level obtained after $\mathrm{KCl}$ addition. The decrease observed in Fig. $5 B$ can be prevented, e.g., by a more thorough treatment with cation exchanger, thus preventing a decrease in fluorescence caused by $\mathrm{Na}^{+}$ions. In summary, these findings are consistent with the concept that an interaction of MCS factors with $\mathrm{Na}, \mathrm{K}$-ATPase leads to changes of the $\mathrm{E}_{1}$ conformation that modify the ion-binding properties of the enzyme. 


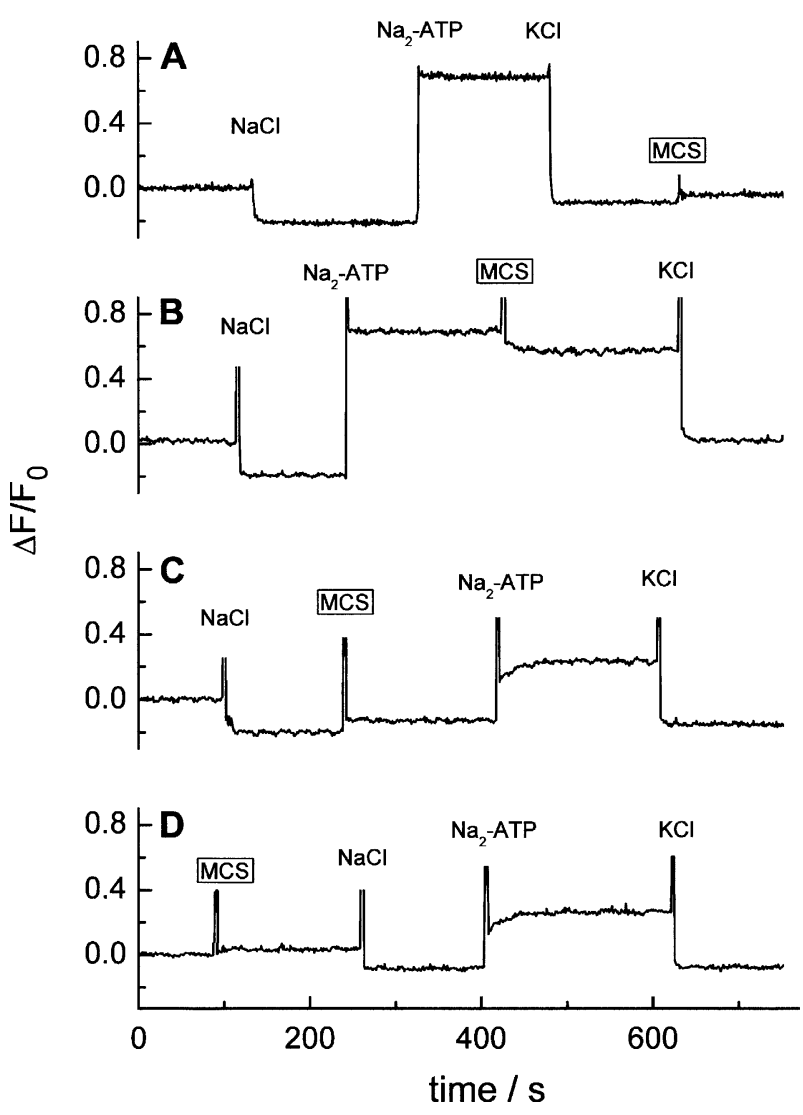

Fig. 5. Standard experiments with RH421 $(0.1 \mu \mathrm{M})$ with addition of $1.96 \mu \mathrm{M}$ MCS factors to each of the standard enzyme states $(A)$ $\left(\mathrm{K}_{2}\right) \mathrm{E}_{2},(B) \mathrm{P}-\mathrm{E}_{2},(C) \mathrm{E}_{1} \mathrm{Na}_{3}$, and $(D) \mathrm{E}_{1}$. Buffer composition: 30 $\mathrm{mM}$ imidazole, $1 \mathrm{mM}$ EDTA, $5 \mathrm{mM} \mathrm{MgCl}_{2}$, $\mathrm{pH}$ 7.2. Standard additions of $25 \mathrm{mM} \mathrm{NaCl}, 0.5 \mathrm{mM} \mathrm{Na} 2 \mathrm{ATP}, 10 \mathrm{mM} \mathrm{KCl}$. Temperature $21^{\circ} \mathrm{C}$.

\section{$\mathrm{H}^{+}$Pathway}

In order to gain insight into the inhibitory action of the MCS factors in the $E_{1}$ conformation, binding of cations that enter the binding sites of the $\mathrm{Na}, \mathrm{K}$ ATPase, $\mathrm{H}^{+}, \mathrm{K}^{+}$, and $\mathrm{Na}^{+}$, was studied in the presence of $0-3 \mu \mathrm{M}$ MCS factors. Investigating the $\mathrm{pH}$ dependence of the inhibitor-protein interaction in experiments with fluorescent styryl dyes, $\mathrm{Na}, \mathrm{K}$ ATPase was titrated with MCS factors in the absence of $\mathrm{Na}^{+}$and $\mathrm{K}^{+}$ions. Additions of the inhibitor led to an increase in fluorescence (Fig. 6). According to the detection mechanism of the styryl dye RH421, a fluorescence increase corresponds to a removal of positive charges from the membrane dielectric (Pedersen et al., 2001). At pH 7 and in the absence of any other monovalent metal ions, the $\mathrm{Na}, \mathrm{K}$-ATPase binds in the average 1.7 protons (Apell \& Diller, 2002). As the fluorescence increase was highest in buffers with highest proton concentrations, a correlation was obvious. Since the maximum relative fluorescence change was about $20 \%$, this is approximately the fluorescence change to be ex- pected, when one proton is removed from the protein, since a fluorescence increase of $60 \%$ is observed when the $\mathrm{Na}, \mathrm{K}-\mathrm{ATPase}$ performs a transition from $\mathrm{E}_{1} \mathrm{Na}_{3}$ to $\mathrm{PE}_{2}$, and three elementary charges are released from the binding sites in the membrane domain of the pump.

When the steady-state fluorescence level upon addition of $2.78 \mu \mathrm{M}$ MCS factors was measured at various buffer $\mathrm{pH}$ (and in the absence of other monovalent cations) the fluorescence declined with increasing $\mathrm{pH}$ (Fig. 6), in contrast to the expectations that at higher $\mathrm{pH}$ the binding equilibrium in the reaction $\mathrm{E}_{1} \leftrightarrow \mathrm{H}_{2} \mathrm{E}_{1}$ should be shifted to the left side. In ATPase activity assays a dependence of inhibitor activity on buffer $\mathrm{pH}$ was observed under substrate conditions that kept the enzyme activity in the absence of inhibitor under maximum turnover (Fig. 4). This observation alone is not sufficient to derive a quantitative $\mathrm{pH}$ dependency for the activation of MCS factors, as the effect is small and-as we shall see later-not only depends on protons but also on the other cations, which are present in excess in the presented ATPase assay. The $\mathrm{pH}$-dependent activation procedure for MCS factors as well as the $\mathrm{pH}$ dependence in Fig. 6, led us to introduce a $\mathrm{pH}$ dependent inhibitor activation term,

$A\left(c_{\mathrm{MCS}}, c_{\mathrm{H}}\right)=c_{\mathrm{MCS}} \cdot \frac{\left[c_{\mathrm{H}}\right]^{n h}}{K I^{n h}+\left[c_{\mathrm{H}}\right]^{n h}}$

Later on - after analysis of the $\mathrm{Na}^{+}$, and $\mathrm{K}^{+}$pathways - it had to be extended with variables accounting for dependencies on $\mathrm{Na}^{+}$and $\mathrm{K}^{+}$ions:

$$
\begin{aligned}
& A\left(c_{M C S}, c_{\mathrm{H}}, c_{\mathrm{Na}}, c_{\mathrm{K}}\right)=c_{\mathrm{MCS}} \cdot \\
& \frac{\left[c_{\mathrm{H}}+\left(c_{\mathrm{Na}} \cdot 4 \cdot 10^{-6}\right)+\left(c_{\mathrm{K}} \cdot 3.5 \cdot 10^{-6}\right)\right]^{n h}}{K I^{n h}+\left[c_{\mathrm{H}}+\left(c_{\mathrm{Na}} \cdot 4 \cdot 10^{-6}\right)+\left(c_{\mathrm{K}} \cdot 3.5 \cdot 10^{-6}\right)\right]^{n h}}
\end{aligned}
$$

Analysis of data with Eq. 1, as shown in Fig. 6, and similar studies in dependence of the $\mathrm{Na}^{+}$and $\mathrm{K}^{+}$ concentration in the buffer with Eq. 2 (see below) led to an effective inhibitor concentration $A$, which is a function of the concentration of MCS factors, $c_{\text {MCS }}$, and the concentration of the cations present, $c_{\mathrm{H}}, c_{\mathrm{Na}}$, and $c_{\mathrm{K}}$. The value of $A$ in Figs. 6-8 does not affect the shape of the MCS concentration dependence but only the fluorescence level at saturating concentrations. The value of $A$ depends on an effective ion concentration, in which the contribution of $\mathrm{Na}^{+}$and $\mathrm{K}^{+}$ions had to be scaled down by the factors given in Eq. 2. The scaling factor in the order of $10^{-6}$ indicates that these ions will contribute significantly to the activation of the MCS factors only at high buffer $\mathrm{pH}$. KI is an effective ion concentration at which the apparent inhibitor concentration is $50 \%$ of the MCS concentration, $c_{\mathrm{MCS}}$, 


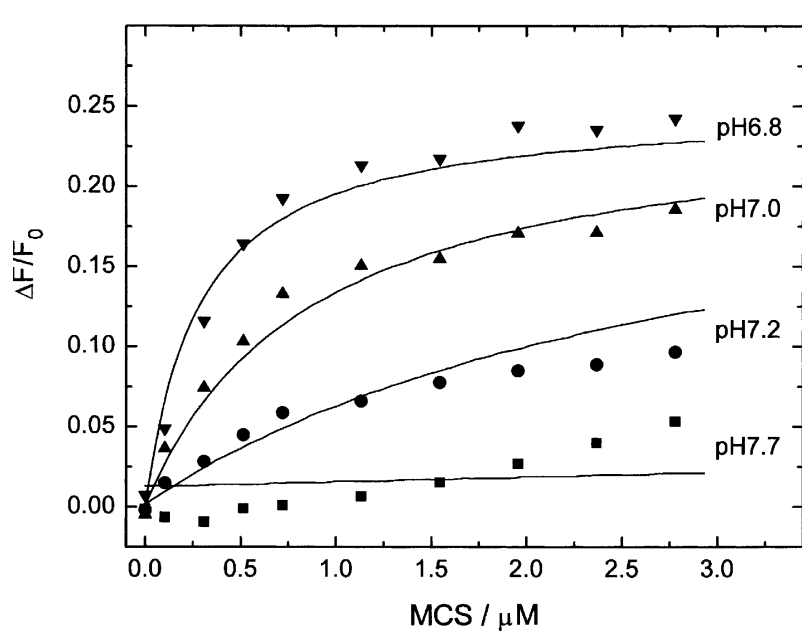

Fig. 6. Results from fluorescence experiment with RH421 and rabbit Na,K-ATPase in $2 \mathrm{ml}$ buffer containing $30 \mathrm{mM}$ imidazole, $1 \mathrm{mM}$ EDTA, $\mathrm{pH} 7.0,20^{\circ} \mathrm{C}$. Titration of MCS to state $\mathrm{E}_{1}$ at varying buffer $\mathrm{pH}$ without $\mathrm{Na}^{+}$or $\mathrm{K}^{+}$ions. Lines represent fits of the total fluorescence calculated on the basis of the model shown in Fig. 9, and the parameters from Table 1 .

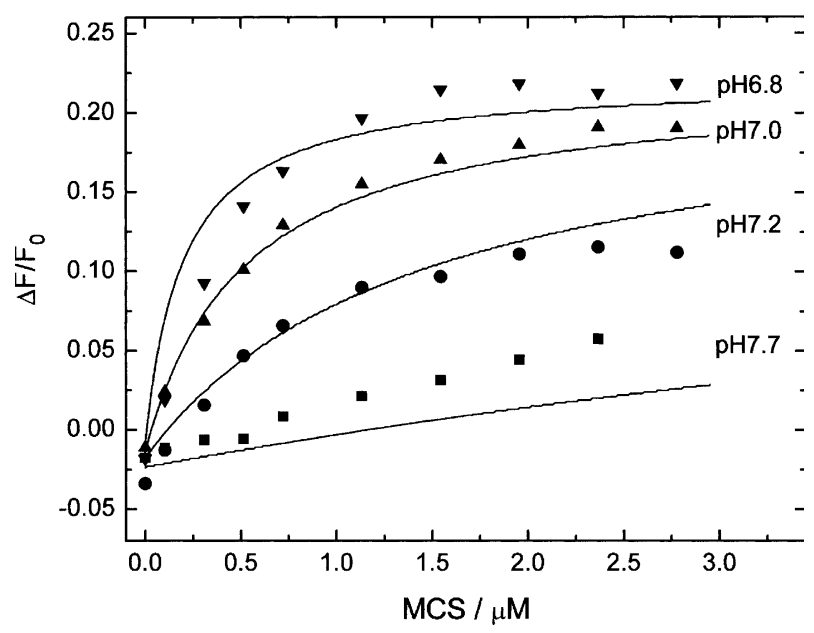

Fig. 7. Results from fluorescence experiment with RH421 and rabbit $\mathrm{Na}, \mathrm{K}$-ATPase (experimental conditions as in Fig. 6). Titration of MCS to state $\mathrm{E}_{1}$ at varying buffer $\mathrm{pH}$ in presence of 10 $\mathrm{mM} \mathrm{KCl}$. Lines represent fits of the total fluorescence calculated on the basis of the model shown in Fig. 9, and the parameters from Table 1 .

present in the buffer. The Hill coefficient, $n h$, can be viewed functionally as a shape factor determining the slope of the curve. A value of $n h>1$ indicates a contribution of more than one cation to promote the activated state of the MCS factors. Fits of Eq. 1 to the experimental data in Fig. 6 led to $K I=2.14 \times 10^{-7} \mathrm{M}$ (pKI 6.67) and $n h=4.2$. (The scaling factors for the $c_{\mathrm{Na}}$ and $c_{\mathrm{K}}$ in Eq. 2 were determined from fits to the data in Fig. 7 and 8, respectively.)

This additional correction of inhibition control in the model led to a reasonable fit of the experimental data (Fig. 6). In conclusion, the previously reported, linear $\mathrm{H}^{+}$pathway (Apell \& Diller, 2002) has to be extended by another reaction step that leads to an MCS-inhibited state with a single proton bound to the Na,K-ATPase, as shown in Fig. 9, Box I. The $\mathrm{pH}$-dependent inhibitor activity has to be introduced into the model to account for the experimentally observed $\mathrm{pH}$-dependent enzyme activity and fluorescence changes. Since protons are present in the buffers at any time, the following analysis of the $\mathrm{K}^{+}$ pathway and the $\mathrm{Na}^{+}$pathway will reveal whether the assumption made so far will hold ground in experiments with additional cations present.

$\mathrm{K}^{+}$Pathway

Titrations of Na,K-ATPase by MCS factors in the presence of $10 \mathrm{mM} \mathrm{K}^{+}$ions also resulted in a $\mathrm{pH}$ dependent increase in fluorescence (Fig. 7); similar experiments were also performed in buffers containing $0.5 \mathrm{~mm}$ and $0.05 \mathrm{~mm} \mathrm{KCl}$ (not shown). In order to understand the fluorescence increases in these experiments, the scheme of possible reaction steps was extended to include the well established $\mathrm{K}^{+}$-bound states, $\mathrm{KE}_{1},\left(\mathrm{~K}_{2}\right) \mathrm{E}_{2}$, and $\mathrm{KHE}_{1}$ with equilibrium dissociation constants for the two $\mathrm{K}^{+}$ions being $K_{1}=0.08 \mathrm{~mm}$ for the first $\mathrm{K}^{+}$ion, and $K_{2}=0.12$ $\mathrm{mm}$ for the second $\mathrm{K}^{+}$ion at $\mathrm{pH} 7.2$, as reported before (Schulz \& Apell, 1995). It was not possible, however, to reproduce the detected MCS and $\mathrm{pH}$ dependence. By following the procedure described for the $\mathrm{H}^{+}$pathway, and introducing another inhibitorbound state $\mathrm{KE}_{1} \mathrm{I}$ (resulting in the reaction scheme within box II in Fig. 9), it was possible to match the simulation to the experimental data (Fig. 7). Except for discrepancies at $\mathrm{pH} 7.7(10 \mathrm{~mm} \mathrm{KCl})$ and $\mathrm{pH} 7.2$ $(0.5 \mathrm{~mm} \mathrm{KCl})$ (not shown), this preliminary model is able to describe the fluorescence changes upon addition of MCS factors in presence of $\mathrm{K}^{+}$ions.

\section{$\mathrm{Na}^{+}$PATHWAY}

Since in the presence of $\mathrm{Na}^{+}$ions (and absence of $\mathrm{K}^{+}$ions) again a fluorescence increase is observed when titrating MCS factors to the Na,K-ATPase (Fig. 8), it seems appropriate to assume a similar behavior as described above for the $\mathrm{H}^{+}$and $\mathrm{K}^{+}$ pathways. But the MCS-concentration dependence of the fluorescence changes was more complex in the presence of $\mathrm{Na}^{+}$ions. Due to the stoichiometry of the $\mathrm{Na}, \mathrm{K}$-ATPase, up to three $\mathrm{Na}^{+}$ions bind to the cytoplasmic cation binding sites. Two of them bind to the same site as (and in competition to) $\mathrm{K}^{+}$ions, while the third $\mathrm{Na}^{+}$ion binds to an exclusively selective site (Schneeberger \& Apell, 1999). All three ions are bound electrogenically, although in the case of the first two ions this effect is (partially) obscured by the counter-movement of two protons (Apell \& Diller, 2002). Therefore, the addition of a high 


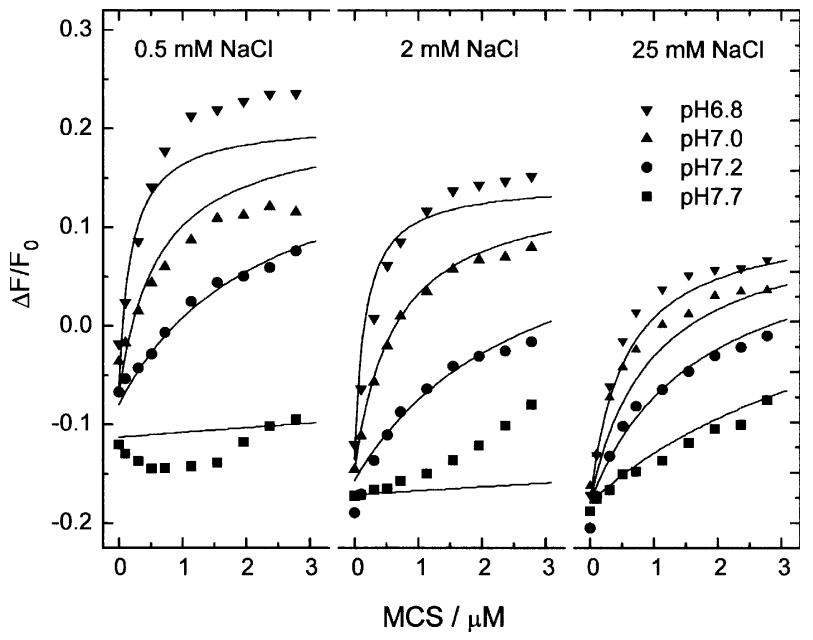

Fig. 8. Results from fluorescence experiment with RH421 and rabbit $\mathrm{Na}, \mathrm{K}-\mathrm{ATPase}$ (experimental conditions as in Fig. 6). Titration of MCS to state $\mathrm{E}_{1}$ at varying buffer $\mathrm{pH}$ and in presence of three concentrations of $\mathrm{NaCl}(0.5 \mathrm{mM}, 2 \mathrm{mM}, 25 \mathrm{mM})$. Lines represent fits of the total fluorescence calculated on the basis of the model shown in Fig. 9, and the parameters from Table 1.

concentration of $\mathrm{Na}^{+}$ions leads to a stronger fluorescence decrease than the addition of a saturating concentration of $\mathrm{K}^{+}$ions (Stürmer et al., 1991). That means, depending on $\mathrm{pH}$ and concentration of $\mathrm{Na}^{+}$ ions, the fluorescence settles at a level between $0 \%$ and $-25 \%$ in the absence of MCS factors. Addition of MCS factors, again, led to a fluorescence increase.

At this point another observation needs an explanation: at low $\mathrm{Na}^{+}$concentrations (e.g., $0.5 \mathrm{~mm}$ $\mathrm{NaCl}$ and $\mathrm{pH}$ 7.7), a small fluorescence decrease was observed upon addition of MCS factors up to $1 \mu \mathrm{M}$, before it starts to increase (Fig. 8, left panel). This effect is caused by a small, residual amount of $\mathrm{Na}^{+}$ ions present in the solution of MCS-factor preparations that is not removed after treatment with cation exchanger during the activation procedure. Control experiments with comparable solutions treated with ion exchanger but without MCS factors produced comparable fluorescence drops. At higher $\mathrm{Na}^{+}$concentrations and/or lower buffer $\mathrm{pH}$ values this effect can be neglected.

The approach to simulate the experimentally observed fluorescence increases upon MCS factor titrations to the $\mathrm{Na}, \mathrm{K}$-ATPase in presence of varying $\mathrm{Na}^{+}$concentrations was the same as described before in case of the $\mathrm{K}^{+}$pathway. In a first step, the well established states $\mathrm{NaE}_{1}, \mathrm{Na}_{2} \mathrm{E}_{1}, \mathrm{Na}_{3} \mathrm{E}_{1}$, and $\mathrm{NaHE}_{1}$ are added to the model of the $\mathrm{H}^{+}$pathway (see Fig. 9, box III). Binding constants for the $\mathrm{Na}^{+}$ions in absence of MCS factors and at $\mathrm{pH}$ 7.0-7.2 were already established before (Schulz \& Apell, 1995, Schneeberger \& Apell, 2001), and are adopted for this simulation as $\mathrm{KNa} 1=1 \mu \mathrm{M}, \mathrm{KNa} 2=0.8 \mathrm{~mm}$, and $\mathrm{KNa} 3=0.9 \mu \mathrm{M}$. The simulations carried out with this model could not match the experimental data nor

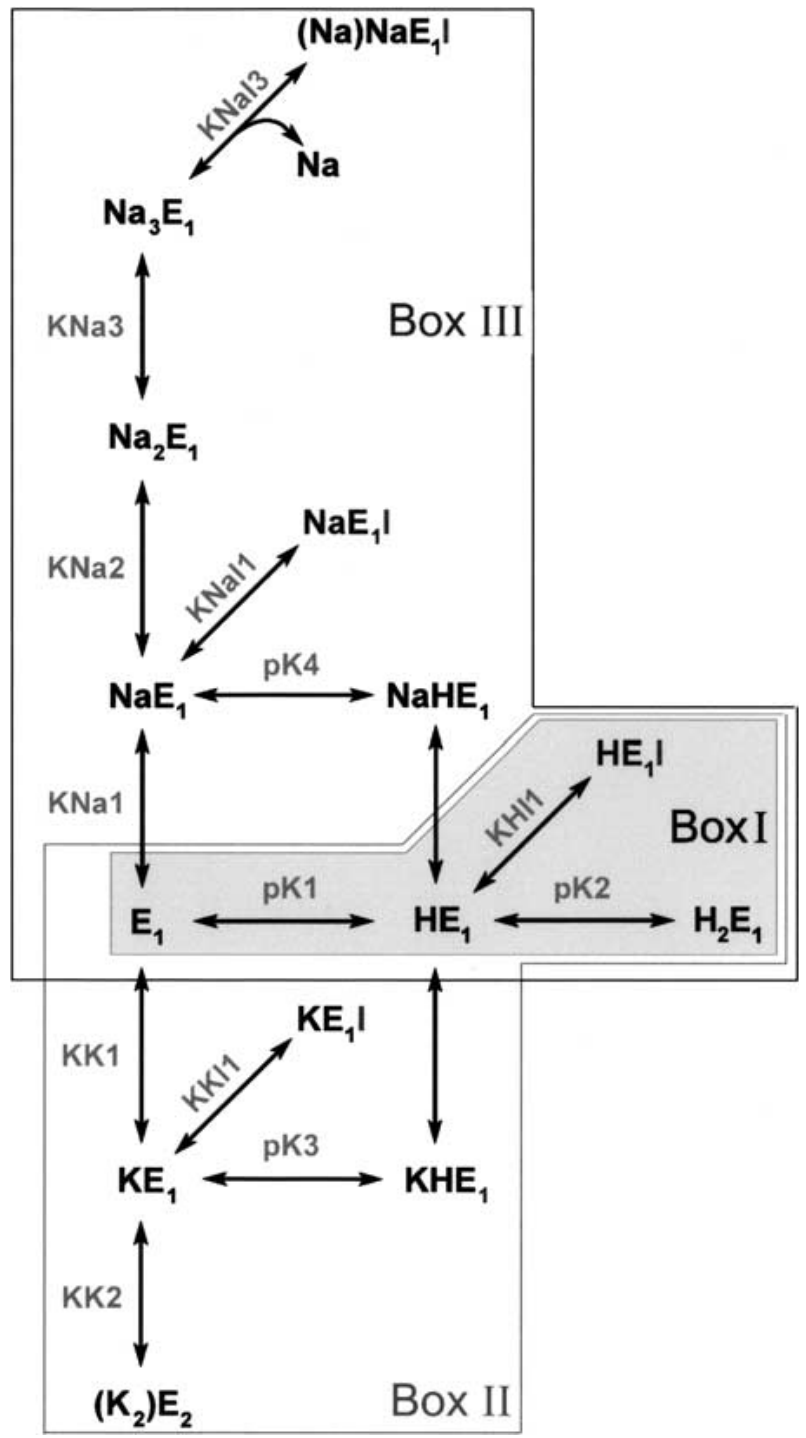

Fig. 9. Complete reaction sequence of ion and MCS-factor binding to the $\mathrm{Na}, \mathrm{K}-\mathrm{ATPase}$ in its $\mathrm{E}_{1}$ conformation. The well-known enzyme states are supplemented by four inhibited states induced by interaction with the MCS factors.

even appropriately represent the trends in fluorescence increases as observed in the experiments (not shown), similar to the respective approach described above for the $\mathrm{K}^{+}$and $\mathrm{H}^{+}$pathway. The $\mathrm{Na}^{+}$ binding affinity is just too high compared to the $\mathrm{H}^{+}$ binding affinity so that the equilibrium constant of the reaction step $\mathrm{HE}_{1} \leftrightarrow \mathrm{HE}_{1} \mathrm{I}(K H I I)$ would have to be much higher in order to shift the equilibrium away from the $\mathrm{Na}^{+}$-bound states. This would be, however, in conflict with the $\mathrm{pH}$ dependence of the observed fluorescence changes when only protons were present (Fig. 6). When trying to simulate the experimental data by following the scheme applied to the $\mathrm{K}^{+}$ pathway, and introducing an inhibitor-bound state to the model with one $\mathrm{Na}^{+}$-ion bound, $\mathrm{NaE}_{1} \mathrm{I}$, the model still could not describe the experiments. A 
particular difficulty appeared at high $\mathrm{Na}^{+}$concentrations when the enzyme is predominantly in state $\mathrm{Na}_{3} \mathrm{E}_{1}$, and the normalized fluorescence level was observed to be shifted towards $-20 \%$. Under this condition the predicted fluorescence increase was much too small (not shown). This is also true for lower $\mathrm{Na}^{+}$concentrations at higher buffer $\mathrm{pH}$ (e.g., $\mathrm{pH}$ 7.7) when the equilibrium state is more easily shifted towards $\mathrm{Na}_{3} \mathrm{E}_{1}$ because the proton concentration that shifts the equilibrium towards $\mathrm{H}_{2} \mathrm{E}_{1}$ would be too small.

These findings indicate that at least one more MCS-factor-induced inhibited state of the $\mathrm{Na}$, $\mathrm{K}$-ATPase is needed to explain the experimentally observed concentration dependencies. As shown below in the Discussion section, the introduction of a state $(\mathrm{Na}) \mathrm{NaE}_{1}$, in which the third $\mathrm{Na}^{+}$, bound to the $\mathrm{Na}^{+}$-specific third site, remains in the protein while the MCS factors induce the release of a $\mathrm{Na}^{+}$ from one of the sites to which also $\mathrm{K}^{+}$or $\mathrm{H}^{+}$are able to bind, allowed a satisfying description of the experimental data by the reaction model represented in box III of Fig. 9.

\section{Discussion}

MCS factors used in this study have been prepared according to the method described previously (Kerek et al., 2002). Very recently a simpler method of preparation has been accomplished and the previously assumed structure has been revised. These data are subject of a forthcoming publication.

The ability of MCS factors to specifically inhibit enzyme activity has been expanded from the $\mathrm{Na}$, $\mathrm{K}-\mathrm{ATP}$ ase to the SR Ca-ATPase, and the gastric $\mathrm{H}$, K-ATPase (Fig. 2B). MCS factors do not distinguish between rat and rabbit Na,K-ATPase (Fig. $2 A$ ), in contrast to ouabain. On the other hand, MCS factors do not inhibit F- and V-type ATPases, which are present in the crude microsomal preparations and which are known to be blocked by azide (Fig. 2C). When these non-P-type ATPases were inhibited, a difference between the residual enzyme activity was still found when ouabain or MCS factors were added. In the presence of ouabain about $17 \%$ of the initial activity was left, while MCS factors led to a $100 \%$ inhibition. This difference is attributed to a ouabaininsensitive $\mathrm{Mg}^{2+}$-ATPase (EC 3.6.1.3) (Jørgensen \& Skou, 1971). Therefore, it is not unreasonable to propose that MCS factors are inhibitors that could apply generally to all P-type ATPases. Further enzymes will have to be tested in order to explore the actual range of inhibited proteins.

By alkaline treatment and subsequent neutralization the MCS precursors can be transformed, presumably into a sodium complex. Mass spectrometric analyses support the proposal that MCS factors are capable of forming complexes with $\mathrm{Na}^{+}$ or other cations (Kerek et al., 2002). The simulations of the reaction scheme presented above required an accounting of MCS-factor activation by $\mathrm{H}^{+}, \mathrm{Na}^{+}$or $\mathrm{K}^{+}$, as reflected by the respective terms in the equation for inhibitor activation (Eq. 2). The chemistry of this activation is hardly understood so far. The dependence of inhibitor activation on protons was explained by a presumed protonation of anionic oxygen groups of the MCS factors. As can be seen in Fig. 4, the Hill coefficient, obtained from the Hill equation when fit to the experimental data, decreases with higher buffer $\mathrm{pH}$, which could be explained by the concept that at high buffer $\mathrm{pH}$ less protonation sites are effective. Fitting the simulations to the experimental data furthermore led to a Hill coefficient $n h=4.2$ in the inhibitor activation term in Eq. 2, suggesting the contribution of significantly more than one proton to obtain the activated state of the MCS factors.

The Na,K-ATPase can be inhibited by MCS factors that induce a change in the apparent affinities of the cytoplasmic cation-binding sites. The inhibited state of the enzyme is (in principle) ion species-independent. As demonstrated above, either a $\mathrm{H}^{+}, \mathrm{K}^{+}$, or $\mathrm{Na}^{+}$can be bound to one of the cytoplasmic ion binding sites in order to produce - together with an MCS factor bound to the protein - an inhibited state. In the absence of $\mathrm{Na}^{+}$and $\mathrm{K}^{+}$the reaction scheme can be proposed straightforward since the fluorescence level of the completely inhibited state is that of the Na,K-ATPase with one proton bound, $\mathrm{HE}_{1} \mathrm{I}$. This leads to the four-state scheme shown in Fig. 9, Box I. In the presence of $\mathrm{K}^{+}$, the previously determined reaction scheme in the absence of the inhibitor was extended by a second inhibited state, again with a single cation bound, $\mathrm{KE}_{1} \mathrm{I}$, Fig. 9, Box, II. This state corresponds to state $\mathrm{HE}_{1} \mathrm{I}$ with the cation exchanged.

With $\mathrm{Na}^{+}$ions the situation is somewhat more complex, as one inhibited state alone does not suffice to explain the observed fluorescence increases, as mentioned above. The fluorescence level at saturating $\mathrm{Na}^{+}$concentrations (Fig. 8) indicated that about two monovalent cations were bound in the MCS-inhibited state, most probably two $\mathrm{Na}^{+}$. At $\mathrm{Na}^{+}$concentrations of up to $2 \mathrm{~mm}$, fluorescence levels at high MCS concentrations were comparable to that obtained at low $\mathrm{pH}$ or high $\mathrm{K}^{+}$. Therefore, we chose to introduce two MCS factor-inhibited states in the case of $\mathrm{Na}^{+}$-bound enzyme as shown in Fig. 9, box III. The first one, $\mathrm{NaE}_{1} \mathrm{I}$, corresponds to the same state that was already introduced in the case of $\mathrm{H}^{+}$or $\mathrm{K}^{+}$ ions, where the cation is in one of the two sites that are accessible for different cations. The second inhibited state, $(\mathrm{Na}) \mathrm{NaE}_{1} \mathrm{I}$, is supposed to be generated from state $\mathrm{Na}_{3} \mathrm{E}_{1}$. In this state the third, $\mathrm{Na}^{+}$specific site is occupied by a $\mathrm{Na}^{+}$(which is indicated 
by the parentheses) and when the MCS factor binds, a protein modification occurs by which one of the two ions in the less ion-specific sites becomes displaced. In total, this state can be interpreted as the first inhibited state plus $\mathrm{a} \mathrm{Na}^{+}$in the third binding site.

Extended numerical simulations proved that without the second $\mathrm{Na}^{+}$-specific inhibited state the $\mathrm{Na}^{+}$- and MCS factor concentration-dependent fluorescence changes (Fig. 8) could not be reproduced. Arguments supporting this choice are: Interaction of MCS factors with the Na,K-ATPase produces an inhibited state in which only a single ion is bound to the two unselective binding sites accessible from the cytoplasm, $\mathrm{XE}_{1} \mathrm{I}$. This common inhibited state can be obtained in the presence of $\mathrm{H}^{+}, \mathrm{K}^{+}$, or (low) $\mathrm{Na}^{+}$. So far it cannot be discriminated whether the MCS factors modify the enzyme in state $\mathrm{XE}_{1}$, or in state $\mathrm{X}_{2} \mathrm{E}_{1}$ with the effect that binding of one of the two ions is destabilized.

With respect to the second inhibited state in presence of high $\mathrm{Na}$, it was previously shown that a fluorescence decrease of $-20 \%$ below the initial reference level depended exclusively on binding of the third $\mathrm{Na}^{+}$ion (Domaszewicz \& Apell, 1999). No other ion but $\mathrm{Na}^{+}$was found to bind to the third ion binding site, and the affinity for $\mathrm{Na}^{+}$binding to the third ion binding site is higher than for the second (Schneeberger \& Apell, 2001). From these findings it was concluded that the third ion binding site becomes available only after the first two sites are occupied. Since this third, $\mathrm{Na}^{+}$-specific binding site most obviously does not contribute to the effects observed in presence of protons or $\mathrm{K}^{+}$ions only, the probability is high that the inhibitor affects the (non-specific) binding sites for the first two ions.

Combining two facts, (1) another state with a fluorescence level lower than +0.2 is necessary to adjust the simulated fluorescence and (2) the fact that the MCS factors most probably affect the first two cytoplasmic binding sites, results in the establishment of another inhibitor-bound state to the model: $\mathrm{Na}_{3} \mathrm{E}_{1}$ $+\mathrm{I} \leftrightarrow(\mathrm{Na}) \mathrm{NaE}_{1} \mathrm{I}+\mathrm{Na}^{+}$(resulting in the reaction scheme within the box III in Fig. 9). The parentheses indicate that the third, specific $\mathrm{Na}^{+}$site remains occupied while the displaced $\mathrm{Na}^{+}$ion is released from one of the (same) two cytoplasmic cation binding sites previously considered affected by MCS factors. This state has two $\mathrm{Na}^{+}$ions bound. Therefore, a fluorescence level of about 0 has to be assigned to it. The fluorescence level of the second inhibited state in the presence of $\mathrm{Na}^{+}, \mathrm{NaE}_{1} \mathrm{I}$, was chosen correspondingly to that of the respective states in the presence of a proton or $\mathrm{K}^{+}$.

In order to simulate the experimental data with this model, small variations of the kinetical parameters result in a somewhat better fit, but the model still showed a weakness in accounting for the fluorescence increases observed at higher $\mathrm{Na}^{+}$concentrations when initially in Eq. 2 the inhibitor activation did not include the $\mathrm{Na}^{+}$-dependent term. Since it was shown that $\mathrm{Na}^{+}$ions affect the activity of the inhibitor (data not shown; see Materials and Methods for the reason why $\mathrm{Na}^{+}$is removed with a cation exchanger from the MCS factor solution), and since the inhibitor can associate with $\mathrm{Na}^{+}$ions (Kerek et al., 2002), the term for inhibitor activation in Eq. 2 was modified to reflect an additional effect of $\mathrm{Na}^{+}$ions. Since this might be true as well for $\mathrm{K}^{+}$ions, another term was added to reflect also an inhibitor activation by $\mathrm{K}^{+}$ ions. This modification was tested and led to an improved fit of the simulated curves to the experimental data.

Applying the optimized model to the data as shown in Fig. 9, and assigning idealized fluorescence levels of $-0.2,0,+0.2$, and +0.4 , depending on whether the enzyme has $3,2,1$, or no cations bound, respectively (based on the idealized assumption that each ion bound to the cytoplasmic cation binding sites should contribute with the same fluorescence change of 0.2), makes it possible to simulate all of the experimental data presented here by adjustment of the binding constants with an approximate fit. No experiments were performed and analyzed so far to specify the actual fluorescence levels of the inhibitorbound states. Therefore, the experimental data were fitted with the model in Fig. 9 by varying both, the assigned fluorescence levels and the binding constants, to receive a simulation with the best possible fit to the experimental data. The final values for these variables are listed in Table 1 . With average values of $-0.18,+0.03 \pm 0.04,+0.23 \pm 0.06,+0.45$ for the differently charged states the increment of 0.2 per elementary charge was well established.

Fig. 10 visualizes the deviation of the simulation from the experimental data. It shows that most of the data points can be represented within the margins of experimental errors when fitted by the reaction sequence shown in Fig. 9. The biggest discrepancy occurred in the data set at $0.5 \mathrm{~mm} \mathrm{NaCl}$ and $\mathrm{pH} 6.8$, and the data sets at high buffer $\mathrm{pH}$ and low cation concentrations. In general, the model has some weaknesses at low $\mathrm{Na}^{+}$and $\mathrm{K}^{+}$concentrations and high buffer $\mathrm{pH}$. This might be caused by minor $\mathrm{Na}^{+}$ contaminations that were still left in the MCS factor solution after cation exchanger treatment. Another - or additional - reason may be a more complex inhibitor-activation behavior by cations that was not taken into account in the above model. The deviating data cluster at $0.5 \mathrm{~mm} \mathrm{NaCl}$ and $\mathrm{pH} 6.8$ (dotted circle in Fig. 10) would stay within the error margins if the buffer $\mathrm{pH}$ is increased from 7.0 to 7.08, since the model is extremely $\mathrm{pH}$-sensitive at low $\mathrm{Na}^{+}$ concentrations. Buffer $\mathrm{pH}$ can be correctly adjusted only up to $+/-0.05 \mathrm{pH}$ units, therefore, such a deviation may be accounted also as easily within the 


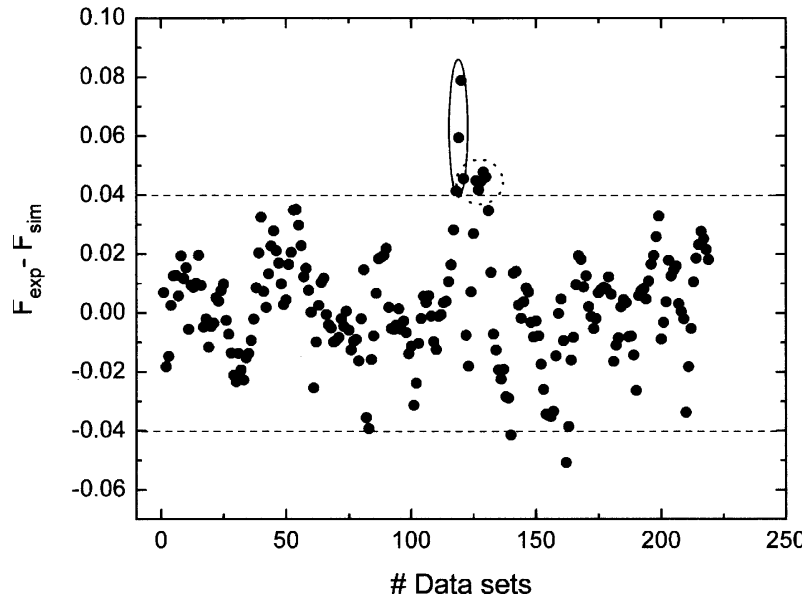

Fig. 10. Visualization of differences between experimental and simulated data. The data points surrounded by a solid circle represent experiments at $\mathrm{pH} 7.7$ and $2 \mathrm{mM} \mathrm{NaCl}$, and the cluster of data points surrounded by a dotted circle represents experiments at pH 6.8 and $0.5 \mathrm{mM} \mathrm{NaCl}$. The dashed lines represent the margins of error in fluorescence experiments with styryl dye RH421.

error margins. Since the other three series of experiments at this $\mathrm{Na}^{+}$concentration can be well fitted with this model, it can be assumed that in principle the model is correct.

\section{Conclusions}

In summary, our study shows that MCS factors are most probably general inhibitors of P-type ATPases. They interact with P-type ATPases on the cytoplasmic side of the proteins, thereby excluding the MCS factors from a role as a classical digitalis-like inhibitor of the $\mathrm{Na}, \mathrm{K}$-ATPase. It is important to point out that MCS factors in their in vitro activated form, as presented here, are not some invariably stable substance but are rather prone to changes in activity that depend on the presence and concentration of $\mathrm{Na}^{+}$, $\mathrm{K}^{+}, \mathrm{H}^{+}$, and possibly other ions. Their mechanism of action involves two possible inhibited states: (1) a state, $\mathrm{X}_{1} \mathrm{E}_{1} \mathrm{I}$, with one $\mathrm{Na}^{+}, \mathrm{K}^{+}$, or $\mathrm{H}^{+}$bound, and (2) a sodium-specific state $(\mathrm{Na}) \mathrm{NaE}_{1} \mathrm{I}$, where at high $\mathrm{Na}^{+}$concentrations the third specific $\mathrm{Na}^{+}$binding site remains occupied in addition to one $\mathrm{Na}^{+}$ion bound to one of the first two ion binding sites to which also other ions can bind. With MCS factors P-type ATPases, at least the Na,K-ATPase, can be arrested in a well-defined state different from those obtained by other inhibitors, such as cardiac glycosides or vanadate.

We thank Milena Roudna for excellent technical assistance. This work was financially supported by the Deutsche Forschungsgemeinschaft (Ap 45/8).

\section{References}

Alpes, H., Apell, H.-J., Knoll, G., Plattner, H., Riek, R. 1988. Reconstitution of $\mathrm{Na}^{+} / \mathrm{K}^{+}$-ATPase into phosphatidylcholine vesicles by dialysis of nonionic alkyl maltoside detergents. Biochim. Biophys. Acta 946:379-388

Anner, B. M., Robertson, J. D., Ting-Beall, H. P. 1984. Characterization of $\left(\mathrm{Na}^{+}+\mathrm{K}^{+}\right)$-ATPase liposomes. I. Effect of enzyme concentration and modification on liposome size, intramembrane particle formation and $\mathrm{Na}^{+}, \mathrm{K}^{+}$-transport. Biochim. Biophys. Acta 773:253-261

Apell, H.-J., Diller, A. 2002. Do ${ }^{+}$ions obscure electrogenic $\mathrm{Na}^{+}$ and $\mathrm{K}^{+}$binding in the $\mathrm{E} 1$ state of the $\mathrm{Na}, \mathrm{K}-\mathrm{ATPase}$ ? FEBS. Lett. 532:198-202

Apell, H.-J., Marcus, M. M. 1986. $\left(\mathrm{Na}^{+}+\mathrm{K}^{+}\right)$-ATPase in artificial lipid vesicles: influence of the concentration of mono- and divalent cations on the pumping rate. Biochim. Biophys. Acta 862:254-264

Apell, H.-J., Marcus, M. M., Anner, B. M., Oetliker, H., Läuger, P. 1985. Optical study of active ion transport in lipid vesicles containing reconstituted Na,K-ATPase. J. Membrane Biol 85:49-63

Bühler, R., Stürmer, W., Apell, H.-J., Läuger, P. 1991. Charge translocation by the Na,K-pump: I. Kinetics of local field changes studied by time-resolved fluorescence measurements. $J$. Membrane Biol. 121:141-161

Domaszewicz, W., Apell, H.-J. 1999. Binding of the third $\mathrm{Na}^{+}$ion to the cytoplasmic side of the $\mathrm{Na}, \mathrm{K}-\mathrm{ATPase}$ is electrogenic. FEBS Lett. 458:241-246

Erdmann, E., Greef, K., and Skou, J. C. 1986. Cardiac Glycosides 1785-1985. Springer-Verlag, New York

Fondacaro, J. D. 1986. Intestinal ion transport and diarrheal disease. Am. J. Physiol 250:G1-G8

Heilmann, C., Brdiczka, D., Nickel, E., Pette, D. 1977. ATPase activities, $\mathrm{Ca}^{2+}$ transport and phosphoprotein formation in sarcoplasmic reticulum subfractions of fast and slow rabbit muscles. Eur. J. Biochem. 81:211-222

Heyse, S., Wuddel, I., Apell, H.-J., Stürmer, W. 1994. Partial reactions of the $\mathrm{Na}, \mathrm{K}-\mathrm{ATPase}$ : determination of rate constants. J. Gen. Physiol. 104:197-240

Hussain, T., Lokhandwala, M. F. 2003. Renal dopamine receptors and hypertension. Exp. Biol. Med. (Maywood.) 228:134-142

Jørgensen, P. L. 1974. Isolation of $\left(\mathrm{Na}^{+}+\mathrm{K}^{+}\right)$-ATPase. Meth. Enzymol. 32:277-290

Jørgensen, P. L., Skou, J. C. 1971. Purification and characterization of $\left(\mathrm{Na}^{+}+\mathrm{K}^{+}\right)$-ATPase. I. The influence of detergents on the activity of $\left(\mathrm{Na}^{+}+\mathrm{K}^{+}\right)$-ATPase in preparations from the outer medulla of rabbit kidney. Biochim. Biophys. Acta 233:366-380

Kerek, F. 2000. The structure of the digitalislike and natriuretic factors identified as macrocyclic derivatives of the inorganic carbon suboxide. Hypertens. Res. 23:S33-S38

Kerek, F., Stimac, R., Apell, H. J., Freudenmann, F., Moroder, L. 2002. Characterization of the macrocyclic carbon suboxide factors as potent Na,K-ATPase and SR Ca-ATPase inhibitors. Biochim. Biophys. Acta 1567:213-220

Lang, F., Busch, G. L., Ritter, M., Volkl, H., Waldegger, S., Gulbins, E., Haussinger, D. 1998. Functional significance of cell volume regulatory mechanisms. Physiol Rev. 78:247-306

Pedersen, M., Roudna, M., Beutner, S., Birmes, M., Reifers, B., Martin, H.-D., Apell, H.-J. 2001. Detection of charge movements in ion pumps by a family of styryl dyes. J. Membrane Biol. 185:221-236

Rabon, E. C., Bin, I. W., Sachs, G. 1988. Preparation of gastric $\mathrm{H}^{+}, \mathrm{K}^{+}$-ATPase. Methods Enzymol. 157:649-654

Schneeberger, A., Apell, H.-J. 2001. Ion selectivity of the cytoplasmic binding sites of the Na,K-ATPase: II. Competition of various cations. J. Membrane Biol. 179:263-273 
Schneeberger, A., Apell, H.-J. 1999. Ion selectivity of the cytoplasmic binding sites of the Na,K-ATPase: I. Sodium binding is associated with a conformational rearrangement. J. Membrane Biol. 168:221-228

Schulz, S., Apell, H.-J. 1995. Investigation of ion binding to the cytoplasmic binding sites of the Na,K-pump. Eur. Biophys. J. 23:413-421

Schwartz, A. K., Nagano, M., Nakao, M., Lindenmayer, G. E., Alien, J. C. 1971. The sodium- and potassium-activated adenosinetriphosphatase system. Meth. Pharmacol. 1:361-388
Stimac, R. 2005. Macrocyclic carbon suboxide derivatives: Novel potent inhibitors of the Na,K-ATPase, and their mechanism of inhibition. Ph.D. thesis, University of Konstanz, Konstanz, Germany, pp. 1-129

Stürmer, W., Bühler, R., Apell, H.-J., Läuger, P. 1991. Charge translocation by the Na,K-pump: II. Ion binding and release at the extracellular face. J. Membrane Biol. 121:163176

Therien, A. G., Blostein, R. 2000. Mechanisms of sodium pump regulation. Am. J. Physiol. 279:C541-C566 